Acta Technologica Agriculturae 4

Nitra, Slovaca Universitas Agriculturae Nitriae, 2015, pp. 97-101

\title{
DO TILLAGE METHODS AFFECT GERMINATION AND SPECIES SIMILARITY OF SOIL WEED SEEDS BANK?
}

\author{
Hassan SHAHGHOLI ${ }^{1}$, Hassan MAKARIAN² ${ }^{2}$, Behzad SHOKATI ${ }^{3 *}$, \\ Ghassem Hossein TALAEI ${ }^{4}$, Mohammad Reza ASGHARIPOUR ${ }^{5}$ \\ ${ }^{1}$ Islamic Azad University, Khomein Branch, Khomein, Iran \\ 2University of Shahrood, Shahrood, Iran \\ ${ }^{3}$ Young Researchers and Elite Club, Maragheh Branch, Islamic Azad University, Maragheh, Iran \\ ${ }^{4}$ Young Researchers and Elite Club, Khorramabad Branch, Islamic Azad University, Khorramabad, Iran \\ ${ }^{5}$ University of Zabol, Sistan and Baluchestan, Iran
}

\begin{abstract}
Cultural practices such as tillage used for crop production influence the composition of the weed seed bank in the soil. In order to investigate the effects of different tillage methods on seed bank properties, species diversity and similarity, two laboratory and greenhouse experiments were carried out as randomized complete block design with four replications in 2011. Treatments included: once tillage per year (T1), twice tillage per year (T2), more than twice tillage (T3) and no tillage (T4). Laboratory results showed that the T3 and T4 treatments had the highest and the lowest observed seeds numbers, respectively. Between the laboratory observed weed seeds, the maximum weed seed numbers were Echinochloa crus-galli and Amaranthus retroflexus in the T3 treatment, while Chenopodium album, Polygonum aviculare and Cuscuta campestris had the highest seed numbers in the T2 treatment. At the greenhouse study, Chenopodium album, Amaranthus retroflexus and Hordeum morinum in the T2 treatment were dominant species. The highest diversity was observed in the T2 treatment, and Chenopodium album and Echinochloa crus-galli were dominant species in the T2 and T3 treatments. Maximum species similarity index was achieved from the T1 and T3 treatments. Thereby this study concluded that increasing of tillage number could affect the similarity index of weed seeds and subsequently alters the weed community composition.
\end{abstract}

Keywords: diversity; germination; Shannon index; Sorenson index; tillage

The compositions of weed communities of agricultural lands vary greatly and are closely linked to cropping history. Species composition and density are influenced by farming practices and vary from field to field and among areas within fields (Buhler et al., 2009). Weed is a plant that interacts with crops, which leads to decreasing of yield quality and quantity. There are a multitude of control methods available to manage weeds. But unfortunately chemical way is the most effective and common manner (Chandramohan et al., 2002). Several negative effects of chemical weed control, however, have been recorded in recent years. Because of negative effects of herbicides on the environment and resistance of weed to herbicides, necessities of non-chemical controlling approaches are being more emphasized. Tillage is often seen as an organic alternative to chemical weed control. Tillage can be very effective in reducing weed populations (Parish, 1990). Tillage practices bring the weed seeds to the top soil layers and expose them to sunlight, resulting in germination, thereby increasing their susceptibility to herbicides and environmental stresses (Buhler, 2002). As some seeds are photoblast, then by preventing of sunlight attaining and decreasing of germination of seeds during the tillage their population could be decreased (XiangJu et al., 2012). Tillage is one of the most important factors in the composition and density of weeds. Different tillage methods could change the weed flora through the influence of residues on soil seeds germination conditions, humidity and soil temperature changes, and weed seeds dispersion in soil (Baskin and Carol, 1980; Abu-Hamdeh, 2003). Tillage is an important component of integrated weed management. Determination of the maximum germination rate under tillage systems is very important in this sense. Thus, comprehensive information about weed density and weed seeds bank properties is necessary for successful weed management (Buhler, 2002). Field seed bank properties are affected by weed population, thereby depend on cultural methods and management practices (Concenço et al., 2011). Cultural practices such as tillage, rotation and inputs uses are the topics of some researches in weed management science. Cardina and Norquay (1997) showed that annual tillage decreased the trend in the viability of soil seed bank. After 8 years just $5 \%$ of primary population were survived and after 17 years it decreased to less than 1\%. Blackshow et al. (1994) reported that different tillage methods affected vertical seeds dispersion in the soil profile. Based on the results of these researchers, the germination and density of weed species was greater in no tillage compared to conventional and minimum tillage. The effect of tillage number on weed seed bank has been reported previously (Buhler et al., 2009; Concenço et al., 
2011). Therefore, more information is needed to determine the effect of various tillage systems on weed seed bank and seedling characteristics. The objectives of this study were to investigate the effects of tillage operations number on germination and species similarity and diversity and to identify dominant species under different tillage number.

\section{Material and methods}

In order to consider the tillage operation number effects on seeds number, germination, species diversity and weed species similarity, two laboratory and greenhouse experiments were carried out at the Faculty of Agriculture, University of Shahrood, Iran in 2011 based on randomized complete block design with four replications. The treatments included once tillage in July ( $\mathrm{T} 1)$, twice tillage in July and October (T2), more than twice tillage in July, October and November (T3) and no tillage (T4). Soil samples were obtained in November. Soil tillage was done by a moldboard plow. Twenty samples per plot were taken at random to determine the seed bank composition. Soil cores, $3.5 \mathrm{~cm}$ in diameter, were divided into $0-15 \mathrm{~cm}$ depths and the 20 samples from each farm were pooled. In this study, cloth bags were used for separating weed seeds (Forcella et al., 2003). For this purpose, the mesh cloth bags (65 meshes) with dimensions $20 \mathrm{~cm} \times$ $15 \mathrm{~cm}$ were used and fabricated with flame. In addition, these bags also have the strength sufficient for various stages of disassembly. The samples were washed and continued until the particles of sand, gravel and plant debris evacuated. The samples were then dried in an appropriate space in open air conditions. Different species of weed seeds were identified under binocular using different keys (Rahman et al., 1995). Other samples (soil) were transferred to the greenhouse for seed emergence evaluation. The soil was air-dried and sieved through a $2 \mathrm{~mm}$ screen to break up large soil clods. The entire sample, minus large rocks and root fragments, was spread in $22 \mathrm{~cm}$ square trays and watered twice daily in the greenhouse. Weed seedlings that emerged were identified, counted, and removed. Seedlings of questionable identity were transplanted into pots (with a $20 \mathrm{~cm}$ diameter, $25 \mathrm{~cm}$ height, and $5 \mathrm{~kg}$ capacity) and grown until their identity could be verified. Watering continued for one week after seedling emergence ceased; then, the soil was air-dried, thoroughly mixed, and rewetted to permit further germination. This process was repeated four times or until no more seedlings emerged. The greenhouse thermostat was set to maintain a temperature of $25{ }^{\circ} \mathrm{C} \pm 3{ }^{\circ} \mathrm{C}$, with no artificial lighting. Seed bank data (counts of seedlings from the germination procedure plus seeds from the extraction process) and weed density in the field were converted to numbers per $\mathrm{m}^{2}$. Seed bank species composition data were used to calculate the indices of species diversity and heterogeneity. The weed species such as Echinochloa crus-galli, Cuscuta campestris, Chenopodium album, Polygonum aviculare, Amaranthus retroflexus, Hordeum morinum and Aegilops spp. were found in the experimental field. Diversity index was calculated according to Shannon-Wiener index (1963):

$$
H=-\sum \frac{N}{n i} \cdot \log \left(\frac{N}{n i}\right)
$$

Species similarity among tillage systems was calculated based on Sorenson index (S) (Magurran, 1988):

$$
S=\frac{2 W}{(C+J)}
$$

Data analysis was performed by the SAS and MSTAT-C softwares. Means comparison was calculated by LSD test at $p \leq 0.05$, and figures were drawn in Excel 2010.

\section{Results and discussion}

\section{Laboratory experiment}

According to the data analysis (Table 1 ), tillage number had a meaningful effect on total weed seeds numbers ( $p \leq 0.01)$. The mean comparison of data showed that the maximum seed number belonged to the more than twice tillage treatment (T3) although this treatment had not significant differences with the twice tillage treatment (Figure 1). Total weed seeds numbers in the T3 treatment were about $17.14 \%, 69.14 \%$ and $90.28 \%$ greater than the T2, T1 and T4 treatment, respectively. It seems that by increasing of tillage number weed seed density was increased. Baskin and Carol (1980) reported that spring tillage increased the broadleaf weeds population and decreased the annual narrow leaf weeds compared to no tillage system.

Table 1 Analysis of variance of total weed seed number due to different tillage methods

\begin{tabular}{|l||c|c|}
\hline \multirow{2}{*}{ SV } & df & Means squares \\
\cline { 3 - 3 } & & total weed seed number \\
\hline Block & 3 & 13.39 \\
\hline Treat & 3 & $1386.22^{* *}$ \\
\hline Error & 9 & 36.24 \\
\hline CV (\%) & - & 24.66 \\
\hline \multicolumn{2}{|c|}{ ** Significant at $p \leq 0.01$} \\
\hline
\end{tabular}

Notes: SV - sources of variations; df - degree of freedom; CV - coefficient of variation

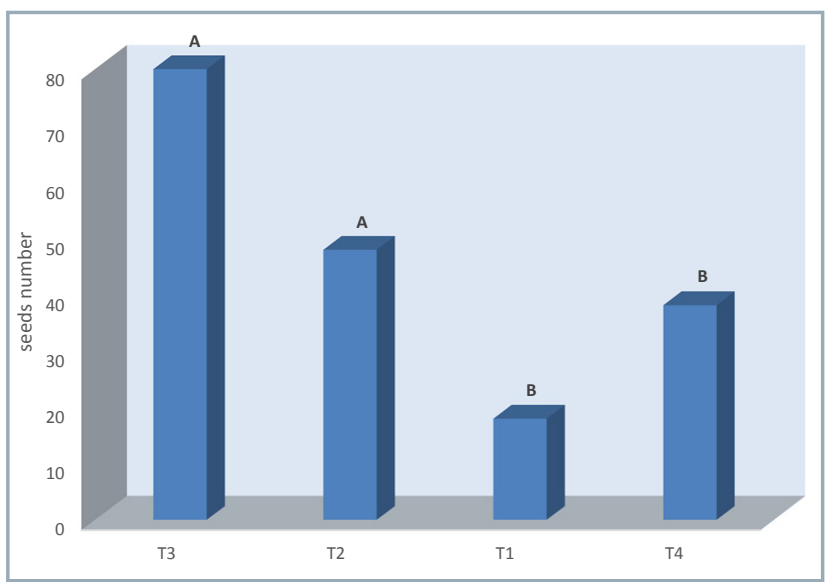

Figure 1 Effect of tillage operation number on total weeds seeds number

T1: once tillage per year, T2: twice tillage per year, T3: more than twice tillage, and T4: no tillage 
Table 2 Analysis of variance of different weed species seeds number due to different tillage methods

\begin{tabular}{|l||c|c|c|c|c|c|c|}
\hline SV & df & $\begin{array}{c}\text { Echinochloa } \\
\text { crus-galli }\end{array}$ & $\begin{array}{c}\text { Chenopodium } \\
\text { album }\end{array}$ & $\begin{array}{c}\text { Cuscuta } \\
\text { campestris }\end{array}$ & $\begin{array}{c}\text { Amaranthus } \\
\text { retroflexus }\end{array}$ & $\begin{array}{c}\text { Polygonum } \\
\text { aviculare }\end{array}$ & $\begin{array}{c}\text { Other weed } \\
\text { Block }\end{array}$ \\
\hline Treat & 3 & 8.62 & 0.22 & 19.97 & 5.13 & 6.53 \\
\hline CV (\%) & 3 & $132.27^{* *}$ & $322^{* *}$ & $17.98^{* *}$ & $8.11^{* *}$ & $8.22^{* *}$ & $0.27^{\text {ns }}$ \\
\hline
\end{tabular}

Table 3 Mean comparison of weed species seed number due to different tillage treatments

\begin{tabular}{|l||c|c|c|c|c|c|}
\hline Treat/weed & $\begin{array}{c}\text { Echinochloa } \\
\text { crus-galli }\end{array}$ & $\begin{array}{c}\text { Chenopodium } \\
\text { album }\end{array}$ & $\begin{array}{c}\text { Cuscuta } \\
\text { campestris }\end{array}$ & $\begin{array}{c}\text { Amaranthus } \\
\text { retroflexus }\end{array}$ & $\begin{array}{c}\text { Polygonum } \\
\text { aviculare }\end{array}$ & Other weed \\
\hline Once tillage (T1) & $1 \mathrm{~b}$ & $4.33 \mathrm{~b}$ & $5.66 \mathrm{a}$ & $0.33 \mathrm{~b}$ & $1.66 \mathrm{a}$ & 0.66 \\
\hline Twice tillage (T2) & $6.66 \mathrm{~b}$ & $24.66 \mathrm{a}$ & $1.33 \mathrm{ab}$ & $3.66 \mathrm{ab}$ & $0.33 \mathrm{~b}$ & 0 \\
\hline More than twice tillage (T3) & $16 \mathrm{a}$ & $20 \mathrm{~b}$ & $0.79 \mathrm{~b}$ & $5.66 \mathrm{a}$ & $1.33 \mathrm{a}$ & 0 \\
\hline No tillage (T4) & $0 \mathrm{~b}$ & $0 \mathrm{~d}$ & $0 \mathrm{~b}$ & $1.33 \mathrm{~b}$ & $2.33 \mathrm{a}$ & 0.33 \\
\hline LSD & 0.043 & 0.02 & 0.029 & 0.025 & 0.039 & 0.006 \\
\hline
\end{tabular}

Different letters in each column indicate significant difference at $p \leq 0.05$

Results indicate that tillage treatments had a significant effect on Echinochloa crus-galli and Chenopodium album seeds number while it had non-significant effect on other weed species (Table 2). According to mean comparison results, the highest Echinochloa crus-galli and Amaranthus retroflexus seeds number was observed in the T3 treatment which had meaningful differences with the T1 and T4 treatments. The lowest weed seeds number was observed in the T4 treatment, except for Polygonum aviculare. Weed seeds density in $\mathrm{T} 3$ and $\mathrm{T} 2 \mathrm{had}$ an increasing trend compared with the T1 and T4 treatments (Table 3).

Some studies have found that weed numbers increased under zero-tillage (e.g. Arshad et al., 1995; Blackshaw et al., 1994; Derpsch, 2003). Others, however, have found that reducing soil disturbance reduced weed populations. For example, seeding with low-disturbance openers reduced weed numbers in a Saskatchewan study (Oliver et al., 2005), and terminating alfalfa stands without tillage reduced weed numbers in the following crop in Manitoba (Ominski and Entz, 2001). Effects vary with weed type. For example, Blackshaw et al. (1994) found that wild buckwheat and common lambsquarters populations were lower in zero-till, even though total weed numbers were higher in zero-till than conventional till.

In zero-till systems, weed seeds remain on the soil surface. The mortality of these seeds is higher than for seeds buried in the soil. Seed predators, such as mice and insects, feed on some of these seeds, preventing them from entering the soil seed bank. Burying weed seeds with tillage operations increases the number of weed seeds in the soil seed bank and may cause these seeds to persist longer than seeds remained on the soil surface, potentially setting the stage for future weed problems. Banting (1966) found that wild oat seeds buried below a depth of $5 \mathrm{~cm}$ remained viable longer than seeds on the soil surface. More recently, Gulden et al. (2003) found that canola seed lost during harvest could enter the state of secondary dormancy and persist for many years in the soil. In this study, the number of persistent seeds found in conventional till plots were higher than in zero-till plots. Tillage can also be used to deplete the weed seed bank in the soil. This practice involves stimulating weed germination with light tillage, either in spring or fall, and then destroying those weeds.

\section{Greenhouse experiment}

Results of the greenhouse experiment analysis of variance (Table 4) revealed that tillage operation number had significant effect on germinated seeds numbers ( $p \leq 0.01)$. Among the seven identified weeds in laboratory just Chenopodium album and Amaranthus retroflexus could germinate in greenhouse conditions. No germination in other weed seeds may be related to seeds dormancy (Benvenuti, 2007). A noticeable amount of wild varieties seeds are in primary dormancy during the harvest (Sagar, 1970). A lack of synchronized germination caused by seeds dormancy makes various problems in their control (Benvenuti, 2007). Seeds dormancy in Chenopodium album L., Rumex acetosella (Baskin and Baskin, 1985), Polygonum aviculare (Bouwmeester and Karssen, 1992) and Avena ludoviciana (Foley, 2001) had been previously reported.

Table 4 Analysis of variance of total germinated seeds due to different tillage methods

\begin{tabular}{|c|c|c|}
\hline \multirow[t]{2}{*}{ SV } & \multirow[t]{2}{*}{ df } & Means squares \\
\hline & & total germinated seeds \\
\hline Block & 3 & 24.39 \\
\hline Treat & 3 & $811.22 * *$ \\
\hline Error & 9 & 21.84 \\
\hline CV (\%) & - & 3.55 \\
\hline
\end{tabular}

As shown in Table 5, the effect of tillage number on all weed species germination was significant $(p \leq 0.01)$, except for 
Table 5 Analysis of variance of weed species seeds germination due to different tillage operation number

\begin{tabular}{l||c|c|c|c|c|}
\hline SV & df & Hordeum morinum & Chenopodium album & Amaranthus retroflexus & Aeigilops spp. \\
\hline Block & 3 & 15.22 & 4.16 & 0.22 \\
\hline Treat & 3 & $413.56^{* *}$ & $58.83^{* *}$ & $1.22^{n s}$ \\
\hline CV (\%) & - & 3.44 & 1.70 & 0.06 \\
\multicolumn{5}{r}{} \\
\end{tabular}

Table 6 Means comparison of weed species seed germination in response of tillage operation number

\begin{tabular}{|l||c|c|c|c|}
\hline Treat/weed & Hordeum morinum & Chenopodium album & Amaranthus retroflexus & Aeigilops spp. \\
\hline Once tillage (T1) & $0.75^{\mathrm{b}}$ & $0^{\mathrm{b}}$ & $1.25^{\mathrm{a}}$ & $0^{\mathrm{b}}$ \\
\hline Twice tillage (T2) & $21.25^{\mathrm{a}}$ & $7.75^{\mathrm{a}}$ & $0.25^{\mathrm{a}}$ & $0.75^{\mathrm{a}}$ \\
\hline More than twice tillage (T3) & $2.25^{\mathrm{b}}$ & $2.25^{\mathrm{b}}$ & $0^{\mathrm{a}}$ & $0^{\mathrm{a}}$ \\
\hline No tillage (T4) & $0^{\mathrm{b}}$ & $0^{\mathrm{b}}$ & $0.25^{\mathrm{a}}$ & $0^{\mathrm{a}}$ \\
\hline LSD & 6.79 & 2.96 & 1.25 & 0.39 \\
\hline
\end{tabular}

Different letters in each column indicate significant difference at $p \leq 0.05$

Table 7

Biodiversity indices and species dominant of weed seeds bank in different tillage treatments

\begin{tabular}{|l||c|c|c|c|}
\hline & No tillage (T4) & Once tillage (T1) & Twice tillage (T2) & More than twice tillage (T3) \\
\hline \hline Shannon index & 0.88 & 0.96 & 1.41 & 1.16 \\
\hline
\end{tabular}

Amaranthus retroflexus. The comparison of means of data showed (Figure 2) that the maximum seeds germination percentage of Chenopodium album,

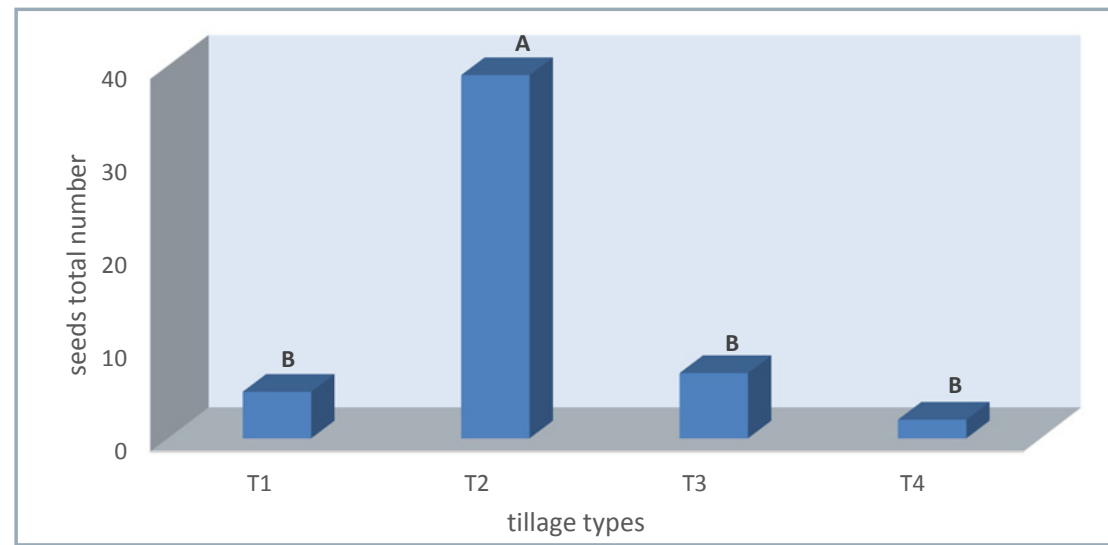

Figure 2 The means of total weed seeds germinated in response to different tillage operation number

T1: once tillage per year, T2: twice tillage per year, T3: more than twice tillage, and T4: no tillage

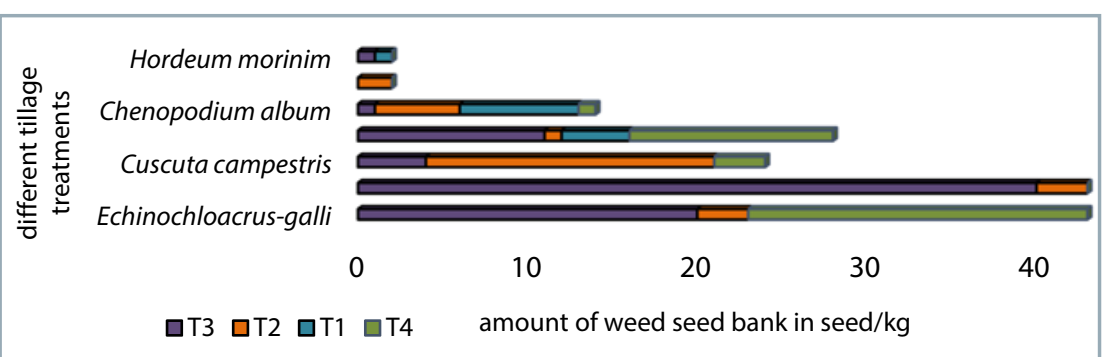

Figure 3 Abundance of weed seeds number under different tillage treatments T1: once tillage per year, T2: twice tillage per year, T3: more than twice tillage, and T4: no tillage
Hordeum morinum and Aeigilops spp. was observed in the T2 treatment which had meaningful differences with other treatments (Table 6). This result was diversity in all tilled treatments was less than 1.44, while the maximum and minimum Shannon diversity index were related to the $\mathrm{T} 2$ and no tillage treatments, respectively. On the other hand, less dominant weed number was observed in the no tillage treatment. The abundance of different weed species in different tillage treatments is shown in Figure 3. The dominance of both Echinochloa crus-galli and Chenopodium album was high in the T2 and T3 treatments, which led to increasing of species diversity.

Tillage can also be used to deplete the weed seed bank in the soil. Increasing of weed germination by increasing of tillage operation number may be related to increasing of soil ventilation and increasing of gas exchange between the seed and environment, scratch of seeds by soil gradient, or machines which led to stimulant germination (Scopel et al., 1994; Benech-Arnold et al., 2000).

In order to investigate the weed seeds bank similarity under different tillage treatments, Sorenson index was used. The similarity matrix index results (Table 8 ) indicated seeds bank similarity in different tillage systems. According to these results, the highest 
Table 8 Sorenson species similarity index of weed seed bank under different tillage treatments

\begin{tabular}{|l||c|c|c|c|}
\hline & Once tillage (T1) & Twice tillage (T2) & No tillage & More than twice tillage (T3) \\
\hline Once tillage (T1) & - & 0.9 & 0.5 & 1.0 \\
\hline Twice tillage (T2) & - & - & 0.66 & 0.9 \\
\hline No tillage & - & - & - & 0.5 \\
\hline More than twice tillage (T3) & - & - & - & - \\
\hline
\end{tabular}

seed bank similarity was observed in once tillage (T1) with more than twice tillage (T3) and twice tillage (T2) with once tillage (T1) treatments, while the lowest was observed in no-tillage with once tillage and no-tillage with more than twice tillage treatments. In comparison of four management systems, Concenço et al. (2011) reported that similarity index was different between no-till and conventional tillage.

\section{Conclusion}

The number of soil tillage had a considerable effect on weed seed bank composition. Results showed that germinated seeds percentage in once tillage, no-tillage and more than twice tillage were less than twice tillage (T2). The modification of the soil environment due to ploughing resulted in an increase in the abundance of weed seeds. The maximum diversity was related to the twice tillage treatment and Echinochloa crus-galli and Chenopodium album were dominant weed species both in the twice and more than twice tillage treatments. It could be concluded that increasing of tillage number could affect the similarity index of weed seeds and subsequently alters the weed community composition in agricultural systems.

\section{References}

ABU-HAMDEH, N.H. 2003. Effect of weed control and tillage system on net returns from bean and barley production in Jordan. In Canadian Biosystems Engineering, vol. 45, pp. 23-28.

ARSHAD, M.A. - GILL, K.S. - COY, G.R. 1995. Barley, canola, and weed growth with decreasing tillage in a cold, semiarid climate. In Agronomy Journal, vol. 87, pp. 49-55.

BANTING, J.D. 1966. Studies on the persistence of Avena fatua. In Canadian Journal of Plant Science, vol. 46, pp. 129-140.

BASKIN, J.M. - CAROL, C.C. 1980. Ecophysiology of secondary dormancy in seeds of Ambrosia arte misifolia. In Ecology, vol. 61, pp. 475-480.

BASKIN, J.M. - BASKIN, C.C. 1985. Does seed dormancy play a role in the germination ecology of Rumex crispus? In Weed Science, vol. 33, pp. 340-343.

BENECH-ARNOLD, R.L. - SÁNCHEZ, R.A. - FORCELLA, F. - KRUK, B.C. GHERSA, C.M. 2000. Environmental control of dormancy in weed seed banks in soil. In Field Crops Research, vol. 67, no. 2, pp. 105-122. BENVENUTI, S. 2007. Weed seed movement and dispersal strategies in the agricultural environment. In Weed Biological Management, vol. 7, pp. 141-57.

BLACKSHOW, R.E. - LARNEY, F.O. - LINDWALL, C.W. - KOZUB, G.C. 1994. Crop rotation and tillage effects on weed population in the semi-arid condition prairies. In Weed Technology, vol. 8, pp. 231-237. BOUWMEESTER, H.J. - KARSSEN, C.M. 1992. The dual role of temperature in the regulation of the seasonal change in dormancy and germination of seeds of Polygonum persicaria. In Oecologica, vol. 90, pp. 88-94.
BUHLER, D.D. 2002. Challenges and opportunities for integrated weed management. In Weed Science, vol. 50, pp. 273-280.

BUHLER, D.D. - KOHLE, K.A. - THOMPSON, R.L. 2009. Weed seed bank dynamics during a five-year crop rotation 1. In Weed Technology, vol. 15, pp. 170-176.

CARDINA, J. - NORQUAY, H.M. 1997. Production and seed bank dynamics in sub-threshold velvetleaf population. In Weed Science, vol. 45, pp. 85-90.

CHANDRAMOHAN, S. - CHARUDATTAN, R. - SONODA, R.M. - SINGH, $M$. 2002. Field evaluation of a fungal pathogen mixture for the control of seven weedy grasses. In Weed Science, vol. 2, pp. 204-213.

CONCENÇO, G. - SALTON, J.C. - BREVILIERI, R.C. - MENDES, P.B. SECRETTI, M.L. 2011. Soil seed bank of plant species as a function of long-term soil management and sampled depth. In Planta Daninha, vol. 29, no. 4, pp. 725-736.

DERPSCH, R. 2003. Conservation tillage, no-tillage and related technologies. In Conservation Agriculture, pp. 181-190.

FORCELLA, F. - WEBSTER, T. - CARDINA, J. 2003. Protocols for weed seed bank determination in agroecosystems. In Addendum, I. - Labrada, R. (Eds). Weed Management for Developing Countries, pp. 3-18. FAO - Rome Plant Production and Protection Paper. FAO : Rome.

GULDEN, R.H. - SHIRTLIFFE, S.J. - THOMAS, A.G. 2003. Secondary seed dormancy prolongs persistence of volunteer canola in western Canada. In Weed Science, vol. 51, pp. 904-913.

MAGURRAN, A.E. 1988. Ecological Diversity and its Measurement. London : Croom Helm.

FOLEY, M.E. 2001. Seed dormancy: an update on terminology, physiological genetics, and quantitative trait loci regulating germinability. In Weed Science, vol. 49, no. 3, pp. 305-317.

OLIVER, E. - NYBO, B. - DERKSEN, D. - WATSON, P. 2005. Southwest opener/rotation study: The effect of opener disturbance on weed populations and crop rotations in the dry brown soil. Available at: http://ssca.usask.ca/conference/2000proceedings/Oliver.html

OMINSKI, P.D. - ENTZ, M.H. 2001. Eliminating soil disturbance reduces post-alfalfa annual weed populations. In Canadian Journal of Plant Science, vol. 81, pp. 881-884.

PARISH, S. 1990. A review of non-chemical weed control techniques. In Biological Agriculture and Horticulture, vol. 7, no. 2, pp. 117-137. RAHMAN, A. - JAMES, T.K. - GRBAVAC, N. - MELLSOP, J. 1995. Evaluation of two methods for enumerating the soil weed seedbank. In Proceedings of $48^{\text {th }}$ New Zealand Plant Protection Conference, pp. 95-175.

SAGAR, G.R. 1970. Factors controlling the size of plant population. In Proceedings of $10^{\text {th }}$ Brit. Weed Control Conference, pp. 965-979.

SCOPEL, A.L. - BALLARE, C.L. - RADOSEVICH, S.R. 1994. Photostimulation of seed germination during soil tillage. In New Phytologist, vol. 126, no. 1, pp. 145-152.

SHANNON, C.E. - WEAVER, W. 1963. The Mathematical Theory of Communication. Urbana : University Illinois Press.

XIANGJU, L. - MIRU, Z. - SHOUHUI, W. - HAILAN, C. 2012. Influence of environmental factors on seed germination and seedling emergence of yellow top (Flaveria bidentis). In Pakistan Journal of Weed Science Research, vol. 18, pp. 317-325. 